\title{
Endofitne glive v biotičnem varstvu rastlin pred škodljivimi organizmi in njihov posreden vpliv na rastline
}

\author{
Primož ŽIGON ${ }^{1,2}$, Franci Aco CELAR ${ }^{3}$
}

Received June 12, 2021; accepted October 12, 2021.

Delo je prispelo 12. junija 2021, sprejeto 12. oktobra 2021

\section{Endophytic fungi as biological control agents and their indi- rect effects on plants}

Abstract: The use of entomopathogenic fungi represents one of the most important non-chemical alternatives for pest control in crop production. In addition to their pathogenicity to arthropods, they have many other important effects that favor their use in biological control. They live in plants as endophytes and have an inhibitory effect on plant pathogens. They inhabit the rhizosphere of many plants in natural and agricultural ecosystems and have a stimulatory effect on their growth and development. These recently acquired ecological functions are not yet fully understood, but point to the broader potential of using entomopathogenic endophytic fungi in crop production, not only as biopesticides but also as mycofungicides and growth stimulants (biostimulants). To achieve the full potential of entomopathogenic endophytic fungi in daily agricultural practice, practical application should be considered in the development of commercial products and the application techniques of entomopathogenic endophytic fungi that allow successful colonization of plants should be considered.

Key words: entomopathogenic fungi; endophyte; beneficial organisms; bioinsecticides; Beauveria; Metarhizium
Endofitne glive $\mathbf{v}$ biotičnem varstvu rastlin pred škodljivimi organizmi in njihov posreden vpliv na rastline

Izvleček: Uporaba entomopatogenih gliv predstavlja enega temeljnih ukrepov nekemičnega varstva rastlin pred škodljivci. Poleg patogenosti za členonožce imajo te glive tudi druge lastnosti, zaradi katerih so širše uporabne $\mathrm{v}$ biotičnem varstvu rastlin. V rastlinah živijo kot endofiti in lahko delujejo zaviralno tudi na različne povzročitelje rastlinskih bolezni. Naseljujejo rizosfero številnih rastlin v naravnih in kmetijskih ekosistemih ter delujejo spodbujevalno na njihovo rast in razvoj. Te v zadnjem času dognane ekološke funkcije še niso podrobneje raziskane, vendar kljub temu nakazujejo na širši potencial uporabe entomopatogenih endofitnih gliv pri pridelavi rastlin, ne le kot sredstev za biotično zatiranje škodljivcev, pač pa tudi kot mikofungicidov in sredstev za krepitev rasti in razvoja (biostimulantov). Za umestitev uporabe entomopatogenih endofitnih gliv v vsakdanjo kmetijsko prakso je potrebno pri razvoju komercialnih pripravkov upoštevati praktičnost uporabe in preučiti tehnike nanosa entomopatogenih endofitnih gliv, ki omogočajo uspešno kolonizacijo rastlin.

Ključne besede: entomopatogene glive; endofiti, koristni organizmi, bioinsekticidi; Beauveria, Metarhizium

1 Kmetijski inštitut Slovenije, Oddelek za varstvo rastlin, Ljubljana

2 Korespondenčni avtor, e-naslov: primoz.zigon@kis.si

3 Univerza v Ljubljani, Biotehniška fakulteta, Oddelek za agronomijo, Ljubljana 


\section{UVOD}

\subsection{ENDOFITI}

Endofiti so različne vrste gliv in bakterij, ki živijo v notranjosti rastlinskega tkiva ter so $\mathrm{z}$ rastlinami v mutualističnem odnosu (Wilson, 1995). Dokaze za obstoj endofitizma so odkrili v fosiliziranih ostankih rastlin, kar kaže na vzpostavitev tovrstnih odnosov že vse od pojava prvih kopenskih rastlin (Field in sod., 2015a; Field in sod., 2015b). Endofiti z gostiteljskimi rastlinami tvorijo kompleksne večplastne interakcije, ki imajo pozitivne učinke na rastline. $Z$ namenom prilagoditve in preživetja znotraj rastlin mikroorganizmi vzpostavijo mutualistični odnos v okviru katerega imata oba organizma medsebojno korist (Kogel in sod., 2006; Hardoim in sod., 2015). Kolonizacija rastlinskega tkiva brez povzročanja vidnih posledic vzpostavitve tega odnosa, ki bi se odražal v obliki poškodb rastlinskega tkiva, poteka vsaj del življenjskega kroga endofitnega organizma. Gre torej za okužbo rastlin, ki se ne odraža $v$ pojavu vidnih bolezenskih znamenj (Petrini, 1991). Endofiti so lahko prisotni v rastlinskih tkivih po celotni rastlini ali posameznih organih kot so korenine, steblo, listi, cvetovi, semena itd. Njihov življenjski prostor znotraj rastlin obsega notranjost celic (intercelularno) in/ali se nahajajo le v medceličnem prostoru (intracelularno) (Hardoim in sod., 2015). Endofitni mikroorganizmi pripomorejo $\mathrm{k}$ odzivu in prilagoditvi rastlin na biotske in abiotske strese ter $\mathrm{z}$ vzbujanjem različnih mehanizmov inducirane odpornosti omogočajo le tem premostitev stresnih situacij (Rodriguez in Redman, 2008; Rho in sod., 2018). Endofiti namreč stimulirajo tvorbo signalnih molekul kot so etilen, jasmonska kislina in salicilna kislina, s čimer vplivajo na aktivacijo mehanizmov inducirane odpornosti (Robert-Seilaniantz in sod., 2011). Eden izmed pomembnih odzivov rastlin na stres je tudi tvorba sekundarnih metabolitov. Endofiti posredno vplivajo na povečano tvorbo rastlinskih sekundarnih metabolitov $\mathrm{z}$ aktivacijo genov za njihovo sintezo, določeni endofiti pa sekundarne metabolite, ki so udeleženi $\mathrm{v}$ obrambnih odzivih rastlin, tvorijo tudi sami (Van Wees in sod., 2008; Zamioudis in Pieterse, 2012). Endofiti lahko vplivajo na večjo dostopnost $v$ tleh vezanih hranil in mineralov ter sproščanje le teh $\mathrm{v}$ talno raztopino, s čimer rastlinam omogočajo njihov privzem in tako vplivajo na boljše fiziološko stanje ter prehranjenost gostiteljskih rastlin. Druge prilagoditve rastlin na abiotski stres, ki jih omogočajo endofiti, so povezane s tvorbo rastlinskih hormonov, stresnih proteinov, antioksidantov in encimov, ki povečujejo toleranco rastlin na stresne razmere (Rho in sod., 2018).

Po drugi strani je vzpostavitev mutualističnega odnosa $\mathrm{z}$ rastlinami ključna za preživetje in obstoj nekate- rih endofitov, obligatnih heterotrofov, ki so odvisni od privzema hranil iz rastlinskega tkiva (Bamisile in sod., 2018). Rastline endofitnim organizmom nudijo ustrezno okolje za rast, zagotavljajo vir ogljika in drugih hranil ter $\mathrm{v}$ nekaterih primerih preko prenosa s semenom gostiteljskih rastlin omogoča njihov obstoj in ohranjanje (Hardoim in sod., 2015). Rastline s koreninskimi izločki $\mathrm{v}$ območje korenin privabljajo množico mikroorganizmov. Mikroorganizmi v tleh, patogeni ali nepatogeni, imajo enak potencial za okužbo rastlin. Ta je odvisna od razmer v rizosferi, vrste in odziva gostitelja ter sposobnosti mikroorganizma, da zaobide njegov imunski odziv (Philippot in sod., 2013). Endofiti iz rizosfere vstopajo $\mathrm{v}$ rastlinsko tkivo preko koreninskih laskov in naravnih odprtin. Vstop endifitov in kolonizacijo rastlinskega tkiva pogojuje tvorba specifičnih encimov, signalnih molekul (na primer flavonoidov) in drugih metabolitov, ki omogočajo premostitev obrambnih mehanizmov rastlin in razlikovanje koristnih endofitnih organizmov od drugih potencialno patogenih mikroorganizmov v rizsoferi (Kogel in sod., 2006; Hardoim in sod., 2015).

\subsubsection{Endofitne glive}

Izraz endofiti je prvič uporabil Heinrich Anton de Bary in z njim označil glive, katerih hife preraščajo celice in tkiva avtotrofnih organizmov (Bary, 1866). Prisotnost endofitnih gliv (EG) v rastlinskem tkivu je prvič dokazal E. M. Freeman (Freeman in Ward, 1904), ki je izoliral glivo iz rodu Epichloë iz semen omotne ljuljke (Lolium temulentum L.). Do danes so EG našli v številnih rastlinskih vrstah, ki rastejo praktično na vseh območjih in vrstah rastišč od severnega do južnega pola zemeljske

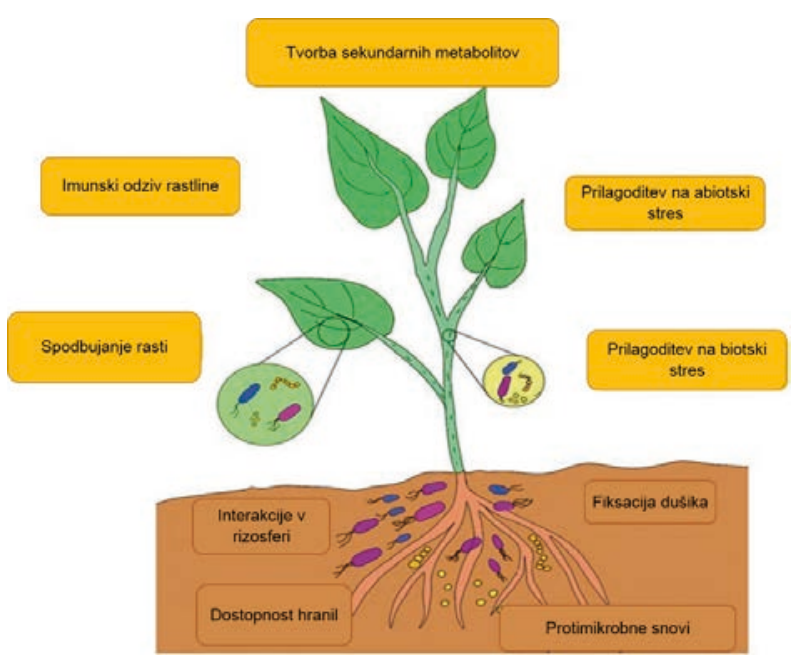

Slika 1: Vpliv endofitov na rast in odziv rastlin na biotske in abiotske stresne dejavnike (Sharma in sod., 2020) 
oble (Saikkonen in sod., 2004; Arnold, 2007; Rodriguez in sod., 2009). EG tvorijo različne vrste sekundarnih metabolitov kot so alkaloidi, cikloheksani, flavonoidi, kinoni in terpeni, ki imajo protimikrobne, antioksidativne, antikancerogene in citotoksične učinke (Rana in sod., 2019; Mantzoukas in Eliopoulos, 2020). Imajo tudi pomembno vlogo pri odzivu rastlin na okužbo/napad rastlinskih patogenov in herbivorov, omogočajo boljšo prehranjenost rastlin, saj povečujejo dostopnost makro in mikro hranil ter omogočajo vezavo atmosferskega dušika (Bacon, 1993; Behie in sod., 2013). Za vzpostavitev simbiotskega odnosa EG tvorijo hidrolitične encime (celulaze, lipaze, proteaze, oksidaze), ki omogočajo premostitev obrambnih mehanizmov rastline in s tem uspešno kolonizacijo rastlinskih tkiv. Znotraj rastlin hife gliv rastejo skozi parenhim tudi vse do ksilema. Sistemična kolonizacija rastlin je značilna za akropetalno (od spodaj navzgor) rastoče hife gliv, torej predvsem v primeru, da gliva izvira iz okuženega semena ali pa vstopa $\mathrm{v}$ rastlino preko korenin (Mantzoukas in Eliopoulos, 2020). Uspešnost kolonizacije rastlin je odvisna od razmer v rizosferi (kompeticija mikroorganizmov), okoljskih razmer (vlaga, temperatura), rastlinske vrste in njenega fiziološkega stanja (Carroll, 1988). Številne vrste EG imajo pomembno vlogo pri odzivu rastlin na okužbo/napad rastlinskih patogenov in škodljivcev. Za EG velja, da imajo načeloma pozitiven vpliv na rastline, saj se okužba, ki jo povzročajo, ne odrazi v bolezenskih znamenjih. Kljub temu za nekatere vrste EG velja, da lahko latentna okužba pod določenimi pogoji, ki so lahko posledica okoljskih sprememb, stresa ali obdobja senescence rastlin, povzroči tudi pojav bolezni (Saikkonen in sod., 2004; Bamisile in sod., 2018).

Na podlagi do sedaj opravljenih raziskav ugotavljajo veliko vrstno pestrost EG, ki izhajajo iz debel zaprtotrosnic (Ascomycota) in prostotrosnic (Basidiomycota) ter poddebla Mucoromycotina. Asimptomatske okužbe so med drugim vzrok za slabo poznavanje in manjšo raziskanost interakcij med glivami in rastlinami, zato je bilo izoliranih in taksonomsko opisanih relativno malo vrst. Endofiti so lahko specializirani na ravni družine, ali pa okužujejo širši krog gostiteljev na različnih rastiščih. Taksonomsko lahko EG razvrščamo v dve skupini glede na družino, ki ji posamezne vrste pripadajo: vrste iz družine Clavicipitaceae (Ascomycota, Hypocreales) kolonizirajo relativno ozek krog gostiteljskih rastlin iz družine trav (Poaceae) kot so Festuca spp., Lolium spp. idr. V drugo skupino sodijo druge glive, ki ne izhajajo iz družine Clavicipitaceae in kolonizirajo širši krog gostiteljskih rastlin (Carroll, 1988; Rodriguez in sod., 2009; Hardoim in sod., 2015). Za enostavnejše razumevanje poznanih kompleksnih interakcij med EG in njihovimi gostiteljskimi rastlinami jih lahko razvrščamo glede na način prenosa med gostiteljskimi rastlinami (horizontal- no ali vertikalno), glede na način kolonizacije in širjenja $\mathrm{v}$ po rastlini (sistemično ali omejeno na posamezne organe oziroma rastlinska tkiva) ali glede na način prehranjevanja (nekrotrofi in biotrofi) (Rodriguez in sod., 2009). Poleg morfološke identifikacije so za določevanje gliv vsekakor pomembne novejše molekulske tehnike na osnovi DNK, ki omogočajo natančnejšo klasifikacijo in filogenetsko opredelitev EG ( Vega in sod., 2009; Bamisile in sod., 2018).

\subsubsection{Entomopatogene glive}

Glive so prevladujoči patogeni členonožcev, med njimi žuželk in pajkovcev, med katerimi so tudi pomembni rastlinski škodljivci. Entomopatogene glive (EPG) so namreč tekom evolucije razvile prefinjene mehanizme izkoriščanja žuželk za zadovoljevanje svojih prehranskih potreb. EPG so paraziti teh organizmov in pri njih povzročajo bolezenska stanja. Med EPG uvrščamo preko 700 različnih vrst, od katerih večina okužuje širok krog gostiteljev, njihovi posamezni sevi pa so bolj patogeni za določene vrste žuželk in pršic (Vega in sod., 2009; Sandhu in sod., 2012). Redke vrste EPG so bolj specializirane in okužujejo ožji krog gostiteljev, kot na primer Aschersonia aleyrodes Webber 1897, ki okužuje le kaparje (Coccoidea) in ščitkarje (Aleyrodidae) (Humber, 2008). Insekticidno učinkovanje EPG je specifično glede na gostiteljske organizme kot so npr. gosenice metuljev (Lepidoptera), uši (Aphidae), resarji (Thrips spp.) in druge kozmopolitske vrste, ki so znani škodljivci kmetijskih rastlin. Do okužbe pride po naključju, ko spore EPG z vetrom ali vodo pridejo $\mathrm{v}$ stik $\mathrm{z}$ gostiteljem in kalijo na površju njegovega telesa. Vanj prodrejo skozi naravne odprtine ali neposredno prek zunanje kutikule. Uspešnost in hitrost kalitve spor je odvisna od okoljskih dejavnikov kot sta vlaga in temperatura, dostopnosti hranil, kisika, pH ter vsebnosti protimikrobnih snovi na kutikuli gostitelja (Sandhu in sod., 2012). Prodor EPG skozi zunanjo epikutikulo poteka mehansko, v večini primerov na podlagi tvorbe specifičnih kaveljčkom podobnih struktur ali apresorijev. Sestava notranjega dela kutikule (prokutikula) je kompleksnejša, sestavljajo jo predvsem hitinske fibrile, beljakovine in lipidi (Hackman, 1953). Prodor glive je zato poleg mehanskega učinka odvisen tudi od biokemičnega vpliva in tvorbe hidrolitičnih encimov, ki razgrajujejo celične strukture v kutikuli (Pedrini in sod., 2007). Okužba je odvisna tudi od učinkovitosti različnih strategij, na podlagi katerih EPG zaobidejo imunski odziv gostitelja. Pri številnih vrstah pride do spremembe načina rasti in tvorbe blastospor, preko katerih pride do uspešne kolonizacije hemocela in privzema hranil iz hemolimfe. Posledica je postopno izčrpavanje, 
podhranjenost in s tem onemogočanje vitalnih funkcij gostitelja (Sandhu in sod., 2012). Poleg tega pri številnih EPG pride do tvorbe toksičnih metabolitov, ki pospešijo pogin gostitelja, olajšajo prodor hif in omogočajo širjenje blastospor v hemolimfi (Vidal in Jaber, 2015). Hife nato prepredejo notranjost telesa in prehajajo na površje kadavra, kjer tvorijo nove spore, ki širijo okužbo naprej.

$\mathrm{O}$ insekticidnih lastnosti EPG in njihovem potencialu za zatiranje škodljivcev so govorili že v 19. stoletju, potem ko je italijanski entomolog Agostino Bassi dokazal, da je okužba z glivo Beuveria bassiana (Bals.Criv.) Vuill. (1912) povzročila bolezensko stanje sviloprejke (Vega in sod., 2009). Z začetkom proizvodnje in množične uporabe kemičnih insekticidov sredi prejšnjega stoletja, prave potrebe po uporabi biotičnih agensov za varstvo rastlin ni bilo, zato do nadaljnjega razvoja tega področja ni prišlo. Danes je pri iskanju okoljsko sprejemljivejših načinov zatiranja rastlinskih škodljivcev uporaba EPG ena ključnih alternativ uporabi kemičnih insekticidov. Prednosti uporabe EPG v primerjavi s sintetičnimi insekticidi so predvsem $\mathrm{v}$ zmanjšanju neželenih učinkov na neciljne organizme in s tem ohranjanje biotske pestrosti agroekosistema ter zmanjšanju ostankov kemijskih spojin v okolju ter s tem manjši vpliv na zdravje ljudi in živali (Vega in sod., 2009; Lacey in sod., 2015). Uporaba entomopatogenih gliv v biotičnem varstvu večinoma temelji na t. i. pristopu preplavnega biotičnega varstva, pri katerem gre za ciljni vnos $\mathrm{z}$ namenom čimprejšnjega zatrtja škodljivca pri čemer nadaljnje razmnoževanje in ohranjanje glive v prostoru ni pomembno. EPG se uporabljajo v obliki tehničnih mikoinsekticidnih formulacij pri katerih je bistvena hitrost učinkovanja, da je dosežena čim prejšnja smrtnost tarčnega organizma (Faria in Wraight, 2007). Za namene masovne proizvodnje pripravkov mora biti produkcija EPG enostavna in cenovno sprejemljiva, pripravki pa morajo dosegati konstantno učinkovitost v poljskih razmerah. Kljub temu, da je več kot 700 vrst EPG iz približno 90 rodov, se v praksi v glavnem uporabljajo le glive iz rodov Beauveria, Metarhizium, Lecanicillium in Isaria, ki ustrezajo prej omenjenim kriterijem (Vega in sod., 2009). Več kot $60 \%$ komercialnih mikoinsekticidov temelji na vrstah Beauveria bassiana in Metarhizium anisopliae (Metchnikoff) Sorokin (1883), ki okužujeta številne rastlinske škodljivce in sta najbolje preučeni vrsti EPG, saj sta se med prvimi uporabljali za namene biotičnega varstva (Sandhu in sod., 2012). Komercialne biopesticidne formulacije pretežno vsebujejo EPG v obliki blastokonidijev, ki se jih nanaša na površje rastlin. Učinkovitost EPG je $\mathrm{v}$ tem primeru $\mathrm{v}$ naravnih razmerah omejena, saj so spore občutljive na UV svetlobo in pomanjkanje vlage (Vega in sod., 2009).

\subsubsection{Entomopatogene endofitne glive}

Vloga EPG pa ni omejena zgolj na zatiranje škodljivcev, pač pa je njihova ekosistemska funkcija, ki posredno vpliva na rast rastlin, mnogo širša. V številnih nedavnih študijah namreč ugotavljajo, da nekatere vrste EPG $\mathrm{z}$ rastlinami tvorijo različne interakcije, kar nakazuje na njihovo endofitno naravo $\mathrm{v}$ smislu kolonizacije rastlinskih tkiv (Mantzoukas in Eliopoulos, 2020). Poleg sposobnosti okuževanja rastlinskih škodljivcev imajo entomopatogeni endofiti (EPGE) lahko tudi antagonistične lastnosti proti povzročiteljem rastlinskih bolezni in $\mathrm{Z}$ naselitvijo $\mathrm{v}$ rizosferi posredno vplivajo na izboljšanje razmer za rast rastlin (Jaber in Enkerli, 2017; Jaber in Ownley, 2018). Ta njihova večstranska vloga in multiplikativni učinki na rastline kažejo na večji potencial EPGE v biotičnem varstvu rastlin, ne le kot sredstev za zatiranje rastlinskih škodljivcev, pač pa tudi v varstvu pred povzročitelji bolezni in posrednimi vplivi na spodbujanje rasti gostiteljskih rastlin (Vega, 2018). Iz rastlinskih tkiv so bile $\mathrm{v}$ preteklih raziskavah izolirane številne glive, ki so znani patogeni rastlinskih škodljivcev in na ta način dokazali njihovo naselitev v rastlinskem tkivu. Za znane pomembnejše vrste EPG kot so Beauveria bassiana, Beauveria brongniartii (Sacc.) Petch, Clonostachys rosea (Link) Schroers, Samuels, Seifert \& W. Gams, Cordyceps farinosa (Holmsk.) Kepler, B. Shrestha \& Spatafora, Neotyphodium spp., Cladosporium spp., Acremonium spp. in Akanthomyces lecanii (Zimm.) Spatafora, Kepler \& B. Shrestha je bila na podlagi postopkov izolacije iz rastlinskih tkiv dokazana njihova $\mathrm{v}$ naravi prisotna endofitna vloga (Preglednica 1). Izmed naštetih je najbolj preučena B. bassiana, ki je splošno razširjena talna gliva in fakultativni endofit, ki okužuje preko 700 vrst žuželk in pršic. B. bassiana se v tleh širi kot saprofit, ki pa ima slabo tekmovalno sposobnost za odmrlo organsko snov, ki ji predstavlja osnovni vir hranil za nadaljnjo rast (Hajek, 1997). Vzpostavitev mutualistične interakcije $z$ rastlinami je zato velikega pomena za obstoj in širjenje glive. Citološke študije kažejo, da nekatere EPGE pretežno rastejo na površju korenin in kolonizirajo le celice epiderma in koreninske skorje ter tako le $\mathrm{v}$ manjši meri vstopajo neposredno $\mathrm{v}$ globje tkivo gostitelja. Z različnimi postopki inokulacije je bila sposobnost kolonizacije rastlinskega tkiva uspešno dokazana tudi za nekatere druge vrste gliv, kot so Metarhizium anisopliae (Metschn.) Sorokī, Fusarium oxysporum Schltdl., Trichoderma lixii (Pat.) P. Chaverri, Fusarium fujikuroi Nirenberg in Trichoderma asperellum Samuels, Lieckf. \& Nirenberg, ki so v različnih raziskavah izkazovale insekticidno delovanje (Akello in Sikora, 2012; Batta, 2013; Muvea in sod., 2014). 


\section{ENTOMOPATOGENE ENDOFITNE GLIVE KOT BIOTIČNI AGENSI ZA VAR- STVO PRED RASTLINSKIMI ŠKODLJIVCI}

EPGE po napadu rastlinskih škodljivcev na različne načine vplivajo na njihovo prehranjevanje in fiziološko stanje. Med pogostejšimi negativnimi posledicami prehranjevanja $\mathrm{z}$ rastlinami, ki so okužene z EPGE se kažejo $\mathrm{v}$ upočasnitvi rasti in razvoja, motnjah hranjenja in zmanjšani sposobnosti razmnoževanja in manjšem številu odloženih jajčec (Vidal in Jaber, 2015). Insekticidne učinke EPGE na škodljive žuželke in pršice so dokazali ob prisotnosti v različnih gostiteljskih vrstah (Preglednica 1). Opravljene so bile številne raziskave, ki pa nimajo enotnih zaključkov o vzrokih za negativne učinke na škodljivce. Hife gliv preraščajo rastlinska tkiva, vendar ni konkretnejših dokazov, da bi znotraj tkiv prihajalo tudi do sporulacije, zato ob prehranjevanju rastlinskih škodljivcev s koloniziranim tkivom, ki ga preraščajo hife EPGE ne pride do neposredne okužbe škodljivca in nastanka mikoz (Vega, 2008). EPG v vlogi endofitov na škodljivce posredno vplivajo preko drugih mehanizmov kot so antibioza, antiksenoza ali krepitev inducirane odpornosti rastlin. S povečano tvorbo signalnih molekul, zlasti jasmonske kisline, se sproži sinteza inhibitorjev in drugih snovi, na primer polifenol oksidaze, ki na škodljivce delujejo toksično. EPGE po napadu škodljivcev lahko vplivajo na hitrejšo aktivacijo rastlinskih obrambnih mehanizmov in močnejši obrambni odziv rastlin (Ownley in sod., 2010; Dara, 2019). V številnih raziskavah omenjajo tudi kopičenje mikotoksinov ali drugih sekundarnih metabolitov, ki jih EPGE izločajo v rastlinskem tkivu in povzročajo različne posledice na škodljivcih (Carroll, 1988; Vega, 2008; Gurulingappa in sod., 2011). Eden od obrambnih mehanizmov, ki ga lahko sprožajo EPGE je tudi sprememba $\mathrm{v}$ sestavi ali zmanjšanje tvorbe hlapnih komponent - kairomonov, ki so za škodljivce predstavljajo pomemben orientir pri iskanju gostitelja (Vega, 2018).

\subsection{UPORABA ENTOMOPATOGENIH ENDOFIT- NIH GLIV V BIOTIČNEM VARSTVU RASTLIN PRED ŠKODLJIVCI}

Sposobnost kolonizacije rastlin je bila dokazana za večino vrst EPG, zaradi česar je njihov potencial za uporabo v biotičnem varstvu še posebej izrazit (Vega, 2018). Življenje znotraj rastlinskega tkiva omogoča manjšo odvisnost od okoljskih razmer in daljše obdobje varstva pred škodljivci. Uspešnost okužbe in kolonizacije rastlinskega tkiva je odvisna od biotskih in abiotskih dejavnikov, kot sta vlaga in temperatura (Vega, 2008). Na okužbo vplivajo tudi interakcije z drugimi mikroorganizmi, lastnosti rastnega medija-substrata, vrsta in starost gostiteljskih rastlin ter velikost glivnega inokluluma (vcepka). Za namene načrtnega vnosa EPGE $\mathrm{v}$ rastline se uporabljajo različne metode inokulacije rastlin kot so foliarni nanos, zalivanje s suspenzijo EPGE, namakanje koreninskega sistema pred sajenjem, pomakanje semen $\mathrm{v}$ suspenzijo glive ali njeno neposredno injiciranje $\mathrm{v}$ rastlinsko tkivo (Bamisile in sod., 2018; Vega, 2018). Foliarni nanos suspenzije konidijev je enostavna in največkrat uporabljena metoda aplikacije $\mathrm{v}$ raziskavah in pri uporabi komercialnih bioinsekticidov. Pri takem načinu vnosa EPGE večinoma pride do lokalne kolonizacije tkiva, na katerega je bila suspenzija nanešena in se ne izrazi $\mathrm{v}$ sistemični okužbi rastline. Pri tem načinu je vstop EPGE skozi listno povrhnjico lahko omejen zaradi manjše zastopanosti naravnih odprtin, kot so na primer listne reže in drugih morfoloških lastnosti listov, ki onemogočajo prodor v rastlinsko tkivo (Tefera in Vidal, 2009). Inokulacija rastlin $\mathrm{v}$ začetnih fazah razvoja, bodisi $\mathrm{z}$ uporabo semen, okuženih z EPGE ali njenim nanosom na površje semen (seed coating), omogoča manjšo izpostavljenost neugodnim vremenskim razmeram in vzpostavitev ustreznih okoljskih razmer za okužbo v tleh (Vidal in Jaber, 2015). Pred sajenjem je inokulacijo sadik z EPGE možno izvesti tudi s pomakanjem sadik v glivno suspenzijo. Inokulacija rastlin ob začetku rasti, ima poleg potencialno dolgotrajnejšega varstva rastlin $\mathrm{v}$ občutljivejših fazah razvoja, tudi pozitiven vpliv na rast in hitrejši mladostni razvoj rastlin (Bamisile in sod., 2018). Okužba z EPGE pred sajenjem ali med rastjo z zalivanjem omogoča varstvo semena in podzemnih delov rastline pred talnimi škodljivci, proti katerim je s foliarnim nanosom EPGE skorajda nemogoče učinkovito ukrepati. Po drugi strani so EPGE, ki jih vnašamo $\mathrm{v}$ tla $\mathrm{z}$ zalivanjem ali neposredno inokulacijo podzemnih delov rastlin, podvržene tekmovanju $\mathrm{z}$ drugimi mikroorganizmi v rizosferi in izpostavljene potencialnim antagonistom. Prav tako ni nujno, da v primeru uspešne kolonizacije korenin pride kasneje tudi do sistemične okužbe nadzemnega dela rastline (Parsa in sod., 2013).

\section{ENTOMOPATOGENI ENDOFITI KOT BIOTIČNI AGENSI ZA VARSTVO PRED RASTLINSKIMI PATOGENI}

Za nekatere EPGE je bilo ugotovljeno, da poleg vpliva na škodljive žuželke in pršice, rastline varujejo tudi pred patogenimi organizmi. V ospredju nedavno opravljenih raziskav je bilo zlasti preučevanje vplivov vrst B. bassiana in Lecanicillium spp. za katere so v različnih raziskavah dokazali antagonistično delovanje predvsem proti različnim povzročiteljem glivičnih bolezni (Ownley 


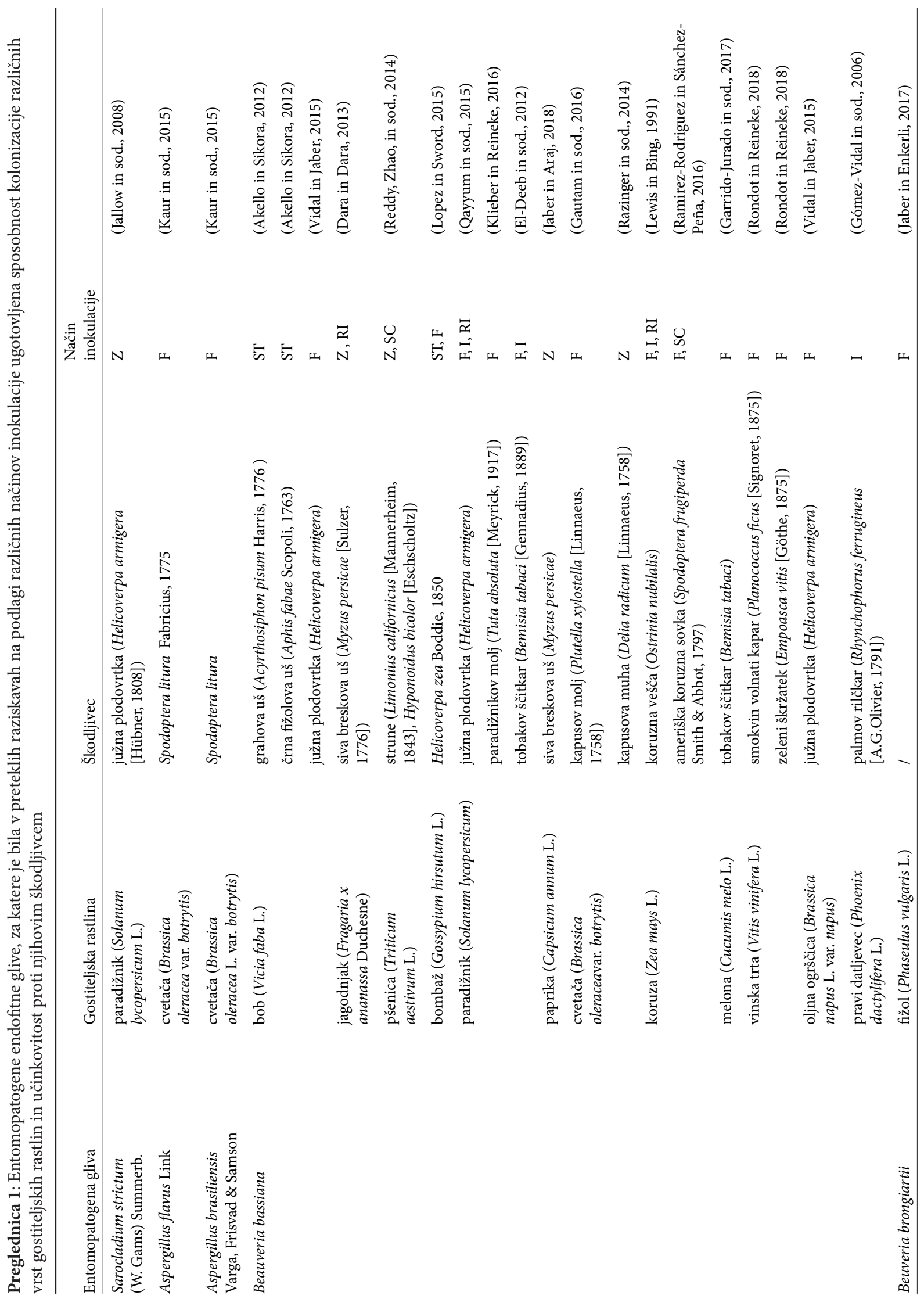




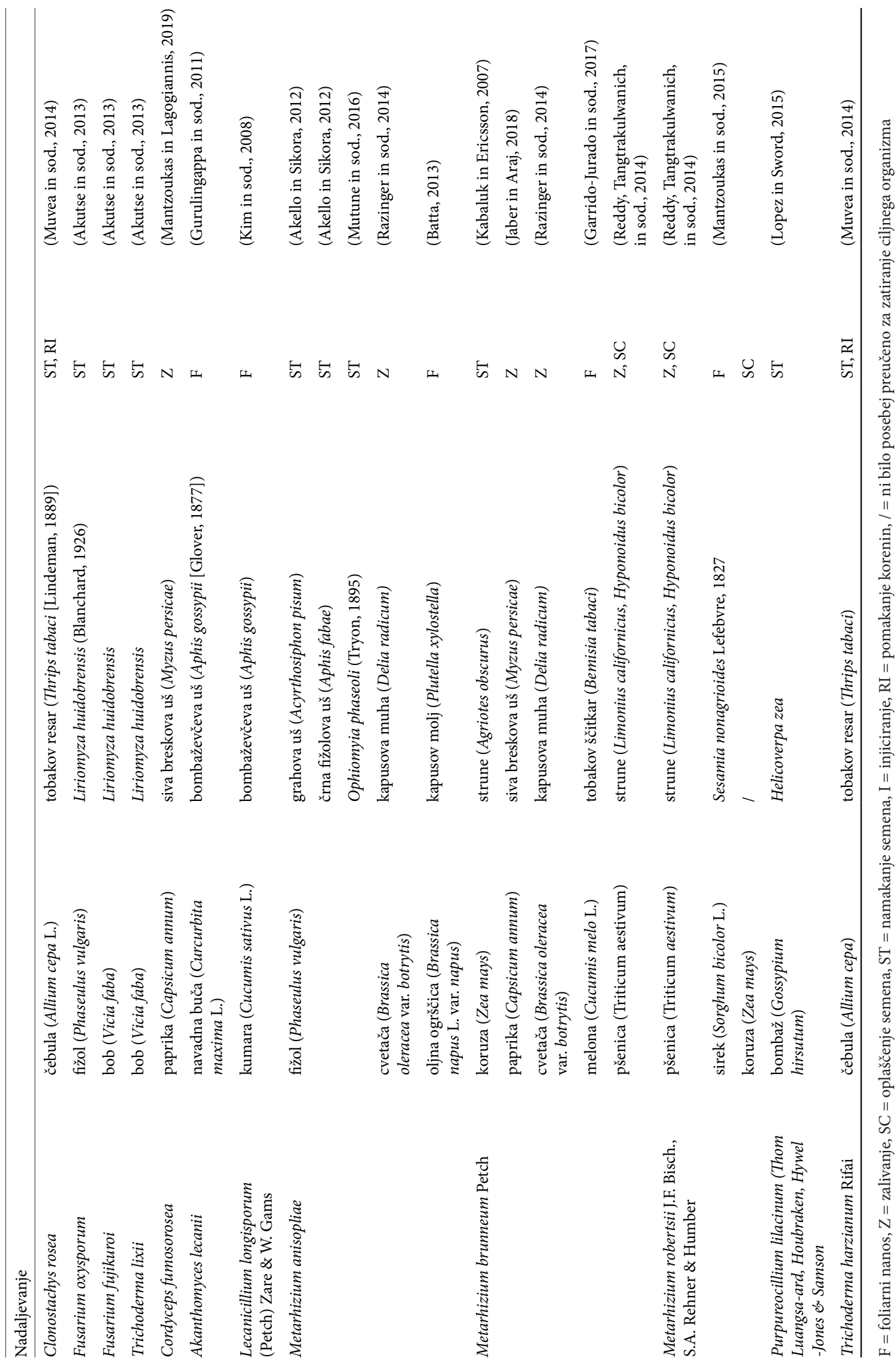


in sod., 2010; Jaber in Ownley, 2018). Kako EPGE vplivajo na zmanjšanje okužb in poškodb zaradi glivičnih in drugih povzročiteljev bolezni (še) ni povsem znano, najverjetneje pa gre za sočasen odziv na več ravneh. Načini delovanja antagonističnih gliv temeljijo na več mehanizmih, ki posamično ali sinergistično delujejo na povzročitelje rastlinskih bolezni preko tekmovanja (kompeticije) za življenjski prostor in hrano, mikoparazitizma, antibioze in vzpodbujanja inducirane sistemične odpornosti rastlin (Ownley in sod., 2010).

Za EPGE Trichoderma spp. in Lecanicillium spp. je značilno, da nekatere patogene glive ob neposrednem stiku parazitirajo (mikoparazitizem) ter jih na ta način slabijo in preprečujejo njihovo rast. Na zmanjšanje okužb z glivnimi patogeni vpliva že sama uspešnost kolonizacije rastlinskih tkiv z EPGE, ki s patogenimi glivami tekmujejo za prostor in hranila (kompeticija). Torej, če je EPGE predčasno prisoten $\mathrm{v}$ rastlini, je za patogeno glivo znotraj rastlinskega tkiva na voljo manj prostora in hranil, zato je možnost okužbe in širjenja manjša. Poleg tega predhodna kolonizacija $\mathrm{v}$ rastlinah sproži sintezo lignina in drugih komponent $\mathrm{v}$ celičnih stenah, ki krepijo mehansko odpornost in onemogočajo penetracijo glivnih hif (Jaber in Ownley, 2018). Antibioza temelji na tvorbi toksičnih hlapnih in nehlapnih organskih molekul in tvorbi encimov, ki so vključeni v razgradnjo celičnih struktur drugih mikroorganizmov. Poleg tega so EPGE tudi bogat vir sekundarnih metabolitov, ki delujejo protimikrobno in citotoksično proti povzročiteljem bolezni. B. bassiana na primer tvori beauvericin, ki ima široko učinkovanje proti številnim mikroorganizmov. Tvorijo ga tudi nekatere druge EPG (Ownley in sod., 2010). Sistemična inducirana odpornost označuje obrambni odziv rastlin na stresne razmere zaradi biotskih ali abiotskih dejavnikov, ki ga spodbudijo nepatogeni organizmi, tudi EPGE. Dokazano je, da predčasna kolonizacija rastline z EPGE poleg vpliva na zmanjšanje posledic napada škodljivcev, lahko vpliva tudi na zmanjšanje okužb in bolezenskih znamenj s strani povzročiteljev bolezni (Dara, 2019). Kolonizacija rastlin z EPGE namreč $\mathrm{v}$ rastlinah lahko poveča vsebnost salicilne kisline in s tem vpliva na izražanje genov za sintezo protimikrobnih encimov kot so hitinaze in glukozidaze (Jaber in Ownley, 2018). Na ta način so obrambni mehanizmi rastline predčasno $\mathrm{v}$ stanju pripravljenosti, kar omogoča rastlinam hitrejši in odločnejši odziv proti povzročiteljem bolezni.

Antagonistične učinke Beauveria spp. so ugotovili $\mathrm{ob}$ prisotnosti $\mathrm{v}$ različnih rastlinah proti različnim povzročiteljem glivičnih bolezni kot so Botrytis cinerea Pers., Fusarium oxysporum, Gaeumannomyces graminis (Sacc.) Arx \& D.L. Olivier, Phytium sp., Rhizoctonia solani J.G. Kühn in Septoria sp. (Renwick in sod., 1991; Bark in sod., 1996; Sang Myeong in sod., 1999). Pri paradižniku in bombažu so ob tretiranju semen z B. bassiana preprečili okužbe kalečih rastlin $\mathrm{z}$ talnima patogenima glivama Pythium myriotylum Drechsler in Rhizoctonia solani. Uporaba istega seva $B$. bassiana je pri bombažu vplivala tudi na zmanjšanje virulentnosti bakterije Xanthomonas axonopodis pv. malvacearum (Smith 1901) Vauterin et al., 1995 (Ownley in sod., 2008). Podobno je B. bassiana omogočila varstvo čebulic čebule pred okužbami s talno glivo Fussarium oxysporum, povzročiteljico fuzarijske gnilobe (Flori in Roberti, 1993). Foliarni nanos suspenzije konidijev komercialnega seva ATCC 74040 glive $B$. bassiana je imel značilen vpliv na zmanjšanje pojavnosti simptomov okužb $\mathrm{z}$ virusom rumenega mozaika na bučkah (ZYMV) in peronospore na vinski trti (Plasmopara viticola (Berk. \& M.A. Curtis) Berl. \& De Toni) (Jaber in Salem, 2014; Jaber, 2015). V eni izmed študij so preučevali tudi vpliv glive Lecanicillium leccanii na zmanjšanje okužb z mokro gnilobo Globisporangium ultimum (Trow) Uzuhashi, Tojo \& Kakish. in pepelovko Podosphaera fuliginea (Schltdl.) U. Braun \& S. Takam. na bučah (Benhamou in Brodeur, 2001).

\section{ENTOPOMATOGENI ENDOFITI KOT SPODBUJEVALCI RASTI}

Vse večje število raziskav potrjuje, da lahko EPGE pomembno vplivajo na hitrejšo rast in razvoj rastlin. Okužba z EPGE namreč lahko stimulira rast koreninskega sistema, s čimer se izboljša privzem hranil in vode $\mathrm{v}$ rastline. Kolonizacija glavnatega zelja z B. bassiana je v lončnem poskusu vplivala na boljšo rast rastlin, ki se je kazala v večji biomasi rastlin in večjim pridelkom, zaradi boljšega privzema hranil (Dara in sod., 2017). Inokulacija krompirja z glivo M. brunneum je povzročila povečanje vsebnosti dušika in fosforja $\mathrm{v}$ rastlinah, kar se je odrazilo $\mathrm{v}$ povečanju biomase, površine listov in pridelka (Krell in sod., 2018). Aplikacija gliv B. bassiana, M. brunneum in C. fumosorosea z zalivanjem je vplivala na boljšo rast zelenih delov rastline ter značilno povečanje pridelka jagod (Dara, 2016). Z izboljšanjem mineralne prehrane EPGE vplivajo na boljšo vitalnost rastlin ter s tem pripomorejo $\mathrm{k}$ blaženju ali preprečevanju posledic abiotskih in biotskih stresnih dejavnikov, med drugim tudi povzročiteljev bolezni. Tako je kolonizacija bučk z glivo $B$. bassiana zaradi vpliva na izboljšanje rasti zmanjšala posledice okužb $\mathrm{Z}$ virusom rumenega mozaika bučke (ZYMV) (Jaber in Salem, 2014). Podobno je na zmanjšanje simptomov koreninske bolezni, ki jo povzroča gliva Fusarium phaseoli (Burkh.) T. Aoki \& O`Donnell, vplivala tudi inokulacija fižola $\mathrm{z}$ glivo Metarhizium robertsii (Sasan in Bidochka, 2013). Posledica kolonizacije rastlin z EPGE je povečanje tvorbe beljakovin vključenih $\mathrm{v}$ fotosintetske reakcije 
in presnovo (Raad in sod., 2019). Okrepljena rast rastlin je lahko tudi posledica povečanja tvorbe fitohormonov $\mathrm{v}$ rastlinah in sideroforov (molekul bogatih $\mathrm{z} \mathrm{Fe} \mathrm{e}^{3+}$ ioni), ki jih tvorijo EPGE in tako vplivajo na boljšo oskrbo rastlin $\mathrm{z}$ železom (Rana in sod., 2019). Zanimivi so izsledki raziskav, ki kažejo, da B. bassiana in nekatere vrste Metarhizium spp. lahko oskrbujejo rastline $\mathrm{z}$ dušikom iz kadavrov parazitiranih žuželk in pršic (Behie in sod., 2012; Behie in Bidochka, 2014). Po okužbi in poginu gostiteljskih žuželk EPGE vzpostavijo endofitno interakcijo, na podlagi katere pride do privzema dušika $\mathrm{v}$ rastline. $\mathrm{Na}$ ta način lahko EPGE izdatno vplivajo na oskrbo rastlin s tem hranilom in kroženje dušika v ekosistemu. Domnevajo, da gre pri tej interakciji med EPGE in rastlinami za mutualističen odnos pri katerem rastline $\mathrm{v}$ zameno za dušik EPGE oskrbujejo z ogljikom. Vpliv EPGE na povečanje rasti je odvisen tudi od načina inokulacije. Vpliv B. bassiana, $B$. brongniartii in $M$. brunneum na boljšo rast rastlin je bil ugotovljen le pri inokulaciji semen, medtem ko pri foliarni aplikaciji EPGE ta odziv ni bil dosežen (Jaber in Enkerli, 2017).

\section{ZAKLJUČEK}

Uporaba EPG za zatiranje škodljivcev je bila preučena v številnih raziskavah. Med najpogosteje uporabljenimi EPG v biotičnem varstvu rastlin so vrste Beauveria bassiana, Metarhizium spp. in nekatere druge, ki so v višjih rastlinah prisotne tudi kot endofiti. Endofitizem EPG omogoča kolonizacijo rastlinskih tkiv in s tem sistemično varstvo rastlin pred škodljivci skozi daljše časovno obdobje. Poleg tega, da vplivajo na zmanjšanje poškodb zaradi napada škodljivcev, lahko EPGE v gostiteljskih rastlinah omogočijo tudi boljšo oskrbo le teh s hranili in s tem njihovo boljšo rast, lažjo premostitev stresnih razmer zaradi abiotskih dejavnikov ter zmanjšanje okužb s patogenimi organizmi. Med drugim se okužba z EPGE v rastlinah lahko odraža tudi v povečani tvorbi sekundarnih metabolitov, ki delujejo toksično na druge organizme, tudi na ljudi. Pri preučevanju načinov inokulacije in posrednih vplivov na gostiteljske rastline ostaja še veliko neznank, prav tako je za širšo uporabo EPGE ključno razumevanje abiotskih in biotskih dejavnikov, ki vplivajo na uspešnost kolonizacije rastlinskega tkiva. Pomemben kriterij pri razvoju in uporabi komercialnih biopesticidov na podlagi EPGE je nepredvidljiva učinkovitost in nekonsistentnost, ki je posledica vpliva številnih dejavnikov na vzpostavitev interakcije $\mathrm{z}$ gostiteljem. Do sedaj je bila večina raziskav v zvezi s preučevanjem EPGE kot biotičnih agensov opravljena v laboratorijskih razmerah, zato je za razvoj celovite strategije zatiranja škodljivcev potrebno več pozornosti nameniti tudi preučevanju ustreznih okoljskih razmer in ustreznih metod inokulacije, ki omogočajo razvoj endofitizma in dolgotrajnejše pozitivne učinke na nivoju celotne rastline.

\section{LITERATURA}

Akello, J., Sikora, R. (2012). Systemic acropedal influence of endophyte seed treatment on Acyrthosiphon pisum and Aphis fabae offspring development and reproductive fitness. Biological Control, 61(3), 215-221. https://doi.org/10.1016/j. biocontrol.2012.02.007

Akutse, K. S., Maniania, N. K., Fiaboe, K. K. M., Van den Berg, J., Ekesi, S. (2013). Endophytic colonization of Vicia faba and Phaseolus vulgaris (Fabaceae) by fungal pathogens and their effects on the life-history parameters of Liriomyza huidobrensis (Diptera: Agromyzidae). Fungal Ecology, 6(4), 293-301. https://doi.org/10.1016/j.funeco.2013.01.003

Arnold, A. E. (2007). Understanding the diversity of foliar endophytic fungi: progress, challenges, and frontiers. In Fungal Biology Reviews (Vol. 21, Issues 2-3, pp. 51-66). Elsevier. https://doi.org/10.1016/j.fbr.2007.05.003

Bacon, C. W. (1993). Abiotic stress tolerances (moisture, nutrients) and photosynthesis in endophyte-infected tall fescue. Agriculture, Ecosystems and Environment, 44(1-4), 123 141. https://doi.org/10.1016/0167-8809(93)90042-N

Bamisile, Bamisope S., Dash, C. K., Akutse, K. S., Keppanan, R., Wang, L. (2018). Fungal endophytes: Beyond herbivore management. In Frontiers in Microbiology (Vol. 9, Issue MAR, p. 544). Frontiers Media S.A. https://doi.org/10.3389/ fmicb.2018.00544

Bamisile, Bamisope Steve, Dash, C. K., Akutse, K. S., Keppanan, R., Afolabi, O. G., Hussain, M., Qasim, M., Wang, L. (2018). Prospects of endophytic fungal entomopathogens as biocontrol and plant growth promoting agents: An insight on how artificial inoculation methods affect endophytic colonization of host plants. Microbiological Research, 217, 34-50. https://doi.org/10.1016/j.micres.2018.08.016

Bark, Y. G., Lee, D. G., Kim, Y. H., Kang, S. C. (1996). Antibiotic properties of an entomopathogenic fungus, Beauveria bassiana, on Fusarium oxysporum and Botrytis cinerea. The Plant Pathology Journal, 12(2), 245-250.

Bary, A. de (Anton). (1866). Morphologie und Physiologie der Pilze, Flechten und Myxomyceten . W. Engelmann,. https:// www.biodiversitylibrary.org/item/211464. https://doi. org/10.5962/bhl.title. 120970

Batta, Y. A. (2013). Efficacy of endophytic and applied Metarhizium anisopliae (Metch.) Sorokin (Ascomycota: Hypocreales) against larvae of Plutella xylostella L. (Yponomeutidae: Lepidoptera) infesting Brassica napus plants. Crop Protection, 44, 128-134. https://doi.org/10.1016/j.cropro.2012.11.001

Behie, S. W., Zelisko, P. M., Bidochka, M. J. (2012). Endophytic insect-parasitic fungi translocate nitrogen directly from insects to plants. Science, 336(6088), 1576-1577. https://doi. org/10.1126/science. 1222289

Behie, Scott W., Bidochka, M. J. (2014). Ubiquity of insectderived nitrogen transfer to plants by endophytic insect- 
pathogenic fungi: An additional branch of the soil nitrogen cycle. Applied and Environmental Microbiology, 80(5), 1553-1560. https://doi.org/10.1128/AEM.03338-13

Behie, Scott W, Padilla-Guerrero, I. E., Bidochka, M. J. (2013). Nutrient transfer to plants by phylogenetically diverse fungi suggests convergent evolutionary strategies in rhizospheric symbionts. Communicative Integrative Biology, 6(1), e22321-e22321. https://doi.org/10.4161/cib.22321

Benhamou, N., Brodeur, J. (2001). Pre-inoculation of Ri TDNA transformed cucumber roots with the mycoparasite, Verticillium lecanii, induces host defense reactions against Pythium ultimum infection. Physiological and Molecular Plant Pathology, 58(3), 133-146. https://doi.org/10.1006/ pmpp.2001.0322

Carroll, G. (1988). Fungal endophytes in stems and leaves: From latent pathogen to mutualistic symbiont. Ecology, 69(1), 2-9. https://doi.org/10.2307/1943154

Dara, S. K. (2016). Impact of entomopathogenic fungi and beneficial microbes on strawberry growth, health, and yield. 1-4. https://ucanr.edu/blogs/blogcore/postdetail. cfm?postnum $=22709$

Dara, S. K. (2019). Non-entomopathogenic roles of entomopathogenic fungi in promoting plant health and growth. In Insects (Vol. 10, Issue 9). MDPI AG. https://doi. org/10.3390/insects 10090277

Dara, S. K., Dara, S. S. (2013). Endophytic colonization and pest management potential of Beauveria bassiana in strawberries. Journal of Berry Research, 3(4), 203-211. https://doi. org/10.3233/JBR-130058

Dara, S. K., Dara, S. S. R., Dara, S. S. (2017). Impact of entomopathogenic fungi on the growth, development, and health of cabbage growing under water stress. American Journal of Plant Sciences, 8, 1224-1233. https://doi. org/10.4236/ajps.2017.86081

El-Deeb, H. M., Lashin, S. M., Arab, Y. A. S. (2012). Reaction of some tomato cultivars to tomato leaf curl virus and evaluation of the endophytic colonisation with Beauveria bassiana on the disease incidence and its vector, Bemisia tabaci. Archives of Phytopathology and Plant Protection, 45(13), 1538-1545. https://doi.org/10.1080/03235408.2012.681246

Faria, M. R. d., Wraight, S. P. (2007). Mycoinsecticides and Mycoacaricides: A comprehensive list with worldwide coverage and international classification of formulation types. $\mathrm{Bi}$ ological Control, 43(3), 237-256. https://doi.org/10.1016/j. biocontrol.2007.08.001

Field, K. J., Pressel, S., Duckett, J. G., Rimington, W. R., Bidartondo, M. I. (2015a). Symbiotic options for the conquest of land. Trends in Ecology Evolution, 30(8), 477-486. https:// doi.org/10.1016/J.TREE.2015.05.007

Field, K. J., Rimington, W. R., Bidartondo, M. I., Allinson, K. E., Beerling, D. J., Cameron, D. D., Duckett, J. G., Leake, J. R., Pressel, S. (2015b). Functional analysis of liverworts in dual symbiosis with Glomeromycota and Mucoromycotina fungi under a simulated Palaeozoic $\mathrm{CO} 2$ decline. The ISME Journal, 10(6), 1514-1526. https://doi.org/10.1038/ ismej.2015.204

Flori, P., Roberti, R. (1993). Treatment of onion bulbs with antagonistic fungi for the control of Fusarium oxysporum f.sp. cepae. Difesa Delle Piante, 16(4), 5-12.

https://eurekamag.com/research/002/724/002724654.php
Freeman, E. M., Ward, H. M. (1904). The seed-fungus of Lolium temulentum L., the darnel. Philosophical Transactions of the Royal Society of London. Series B, Containing Papers of a Biological Character, 196(214-224), 1-27. https://doi. org/10.1098/rstb.1904.0001

Garrido-Jurado, I., Resquín-Romero, G., Amarilla, S. P., RíosMoreno, A., Carrasco, L., Quesada-Moraga, E. (2017). Transient endophytic colonization of melon plants by entomopathogenic fungi after foliar application for the control of Bemisia tabaci Gennadius (Hemiptera: Aleyrodidae). Journal of Pest Science, 90(1), 319-330. https://doi. org/10.1007/s10340-016-0767-2

Gautam, S., Mohankumar, S., Kennedy, J. S. (2016). Induced host plant resistance in cauliflower by Beauveria bassiana. Journal of Entomology and Zoology Studies, 4(2), 476-482.

Gómez-Vidal, S., Lopez-Llorca, L. V., Jansson, H. B., Salinas, J. (2006). Endophytic colonization of date palm (Phoenix dactylifera L.) leaves by entomopathogenic fungi. Micron, 37(7), 624-632. https://doi.org/10.1016/j.micron.2006.02.003

Gurulingappa, P., McGee, P. A., Sword, G. (2011). Endophytic Lecanicillium lecanii and Beauveria bassiana reduce the survival and fecundity of Aphis gossypii following contact with conidia and secondary metabolites. Crop Protection, 30(3), 349-353. https://doi.org/10.1016/j.cropro.2010.11.017

Hackman, R. H. (1953). Chemistry of insect cuticle. I. The water-soluble proteins. The Biochemical Journal, 54(3), 362367. https://doi.org/10.1042/bj0540362

Hajek, A. (1997). Ecology of terrestrial fungal entomopathogens. Advances in Microbial Ecology, 15, 193-249. https:// doi.org/10.1007/978-1-4757-9074-0_5

Hardoim, P. R., van Overbeek, L. S., Berg, G., Pirttilä, A. M., Compant, S., Campisano, A., Döring, M., Sessitsch, A. (2015). The hidden world within plants: ecological and evolutionary considerations for defining functioning of microbial endophytes. Microbiology and Molecular Biology Reviews : MMBR, 79(3), 293-320. https://doi.org/10.1128/ MMBR.00050-14

Humber, R. A. (2008). Evolution of entomopathogenicity in fungi. Journal of Invertebrate Pathology, 98(3), 262-266. https://doi.org/10.1016/j.jip.2008.02.017

Jaber, L. R. (2015). Grapevine leaf tissue colonization by the fungal entomopathogen Beauveria bassiana s.l. and its effect against downy mildew. BioControl, 60(1), 103-112. https://doi.org/10.1007/s10526-014-9618-3

Jaber, L. R., Araj, S. E. (2018). Interactions among endophytic fungal entomopathogens (Ascomycota: Hypocreales), the green peach aphid Myzus persicae Sulzer (Homoptera: Aphididae), and the aphid endoparasitoid Aphidius colemani Viereck (Hymenoptera: Braconidae). Biological Control, 116, 53-61. https://doi.org/10.1016/j.biocontrol.2017.04.005

Jaber, L. R., Enkerli, J. (2017). Fungal entomopathogens as endophytes: can they promote plant growth? Biocontrol Science and Technology, 27(1), 28-41. https://doi.org/10.1080/ 09583157.2016.1243227

Jaber, L. R., Ownley, B. H. (2018). Can we use entomopathogenic fungi as endophytes for dual biological control of insect pests and plant pathogens? In Biological Control (Vol. 116, pp. 36-45). Academic Press Inc. https://doi.org/10.1016/j. 
biocontrol.2017.01.018

Jaber, L. R., Salem, N. M. (2014). Endophytic colonisation of squash by the fungal entomopathogen Beauveria bassiana (Ascomycota: Hypocreales) for managing Zucchini yellow mosaic virus in cucurbits. Biocontrol Science and Technology, 24(10), 1096-1109. https://doi.org/10.1080/09583157. 2014.923379

Jallow, M. F. A., Dugassa-Gobena, D., Vidal, S. (2008). Influence of an endophytic fungus on host plant selection by a polyphagous moth via volatile spectrum changes. ArthropodPlant Interactions, 2(1), 53-62. https://doi.org/10.1007/ s11829-008-9033-8

Kabaluk, J. T., Ericsson, J. D. (2007). Metarhizium anisopliae seed treatment increases yield of field corn when applied for wireworm control. Agronomy Journal, 99(5), 13771381. https://doi.org/10.2134/agronj2007.0017N

Kaur, T., Singh, B., Kaur, A., Kaur, S. (2015). Endophyte-mediated interactions between cauliflower, the herbivore Spodoptera litura, and the ectoparasitoid Bracon hebetor. Oecologia, 179(2), 487-494. https://doi.org/10.1007/ s00442-015-3358-7

Kim, J. J., Goettel, M. S., Gillespie, D. R. (2008). Evaluation of Lecanicillium longisporum, Vertalec ${ }^{\oplus}$ for simultaneous suppression of cotton aphid, Aphis gossypii, and cucumber powdery mildew, Sphaerotheca fuliginea, on potted cucumbers. Biological Control, 45(3), 404-409. https://doi. org/10.1016/j.biocontrol.2008.02.003

Klieber, J., Reineke, A. (2016). The entomopathogen Beauveria bassiana has epiphytic and endophytic activity against the tomato leaf miner Tuta absoluta. Journal of Applied Entomology, 140(8), 580-589. https://doi.org/10.1111/jen.12287

Kogel, K. H., Franken, P., Hückelhoven, R. (2006). Endophyte or parasite - what decides? In Current Opinion in Plant Biology (Vol. 9, Issue 4, pp. 358-363). Elsevier Current Trends. https://doi.org/10.1016/j.pbi.2006.05.001

Krell, V., Unger, S., Jakobs-Schoenwandt, D., Patel, A. V. (2018). Endophytic Metarhizium brunneum mitigates nutrient deficits in potato and improves plant productivity and vitality. Fungal Ecology, 34, 43-49. https://doi.org/10.1016/j. funeco.2018.04.002

Lacey, L. A., Grzywacz, D., Shapiro-Ilan, D. I., Frutos, R., Brownbridge, M., Goettel, M. S. (2015). Insect pathogens as biological control agents: Back to the future. Journal of Invertebrate Pathology, 132, 1-41. https://doi.org/10.1016/j. jip.2015.07.009

Lewis, L. C., Bing, L. A. (1991). Bacillus thuringiensis Berliner and Beauveria bassiana (Balsamo) Vuillimen for european corn borer control: Program for immediate and seasonlong suppression 1. The Canadian Entomologist, 123(2), 387-393. https://doi.org/10.4039/Ent123387-2

Lopez, D. C., Sword, G. A. (2015). The endophytic fungal entomopathogens Beauveria bassiana and Purpureocillium lilacinum enhance the growth of cultivated cotton (Gossypium hirsutum) and negatively affect survival of the cotton bollworm (Helicoverpa zea). Biological Control, 89, 53-60. https://doi.org/10.1016/j.biocontrol.2015.03.010

Mantzoukas, S., Chondrogiannis, C., Grammatikopoulos, G. (2015). Effects of three endophytic entomopathogens on sweet sorghum and on the larvae of the stalk borer Sesa- mia nonagrioides. Entomologia Experimentalis et Applicata, 154(1), 78-87. https://doi.org/10.1111/eea.12262

Mantzoukas, S., Eliopoulos, P. A. (2020). Endophytic entomopathogenic fungi: A valuable biological control tool against plant pests. In Applied Sciences (Switzerland) (Vol. 10, Issue 1, p. 360). MDPI AG. https://doi.org/10.3390/ app 10010360

Mantzoukas, S., Lagogiannis, I. (2019). Endophytic colonization of pepper (Capsicum annum) controls aphids (Myzus persicae Sulzer). Applied Sciences (Switzerland), 9(11), 2239. https://doi.org/10.3390/app9112239

Mutune, B., Ekesi, S., Niassy, S., Matiru, V., Bii, C., Maniania, N. K. (2016). Fungal endophytes as promising tools for the management of bean stem maggot Ophiomyia phaseoli on beans Phaseolus vulgaris. Journal of Pest Science, 89(4), 993-1001. https://doi.org/10.1007/s10340-015-0725-4

Muvea, A. M., Meyhöfer, R., Subramanian, S., Poehling, H. M., Ekesi, S., Maniania, N. K. (2014). Colonization of onions by endophytic fungi and their impacts on the biology of Thrips tabaci. PLoS ONE, 9(9), 108242. https://doi.org/10.1371/ journal.pone.0108242

Ownley, B. H., Griffin, M. R., Klingeman, W. E., Gwinn, K. D., Moulton, J. K., Pereira, R. M. (2008). Beauveria bassiana: Endophytic colonization and plant disease control. Journal of Invertebrate Pathology, 98(3), 267-270. https://doi. org/10.1016/j.jip.2008.01.010

Ownley, B. H., Gwinn, K. D., Vega, F. E. (2010). Endophytic fungal entomopathogens with activity against plant pathogens: Ecology and evolution. BioControl, 55(1), 113-128. https://doi.org/10.1007/s10526-009-9241-x

Parsa, S., Ortiz, V., Vega, F. E. (2013). Establishing fungal entomopathogens as endophytes: towards endophytic biological control. Journal of Visualized Experiments : JoVE, 74, 50360. https://doi.org/10.3791/50360

Pedrini, N., Crespo, R., Juárez, M. P. (2007). Biochemistry of insect epicuticle degradation by entomopathogenic fungi. In Comparative Biochemistry and Physiology - C Toxicology and Pharmacology (Vol. 146, Issues 1-2 SPEC. ISS., pp. 124-137). Elsevier Inc. https://doi.org/10.1016/j. cbpc. 2006.08 .003

Petrini, O. (1991). Microbial ecology of leaves. Spring-Verlag, New York, 179-197. https://doi.org/10.1007/978-1-46123168-4_9

Philippot, L., Raaijmakers, J. M., Lemanceau, P., van der Putten, W. H. (2013). Going back to the roots: the microbial ecology of the rhizosphere. Nature Reviews. Microbiology, 11(11), 789-799. https://doi.org/10.1038/nrmicro3109

Qayyum, M. A., Wakil, W., Arif, M. J., Sahi, S. T., Dunlap, C. A. (2015). Infection of Helicoverpa armigera by endophytic Beauveria bassiana colonizing tomato plants. Biological Control, 90, 200-207. https://doi.org/10.1016/j.biocontrol.2015.04.005

Raad, M., Glare, T. R., Brochero, H. L., Müller, C., Rostás, M. (2019). Transcriptional reprogramming of Arabidopsis thaliana defence pathways by the entomopathogen $B e$ auveria bassiana correlates with resistance against a fungal pathogen but not against insects. Frontiers in Microbiology, 10(MAR), 615. https://doi.org/10.3389/fmicb.2019.00615

Ramirez-Rodriguez, D., Sánchez-Peña, S. R. (2016). Endo- 
phytic Beauveria bassiana in Zea mays: Pathogenicity against larvae of fall armyworm, Spodoptera frugiperda. Southwestern Entomologist, 41(3), 875-878. https://doi. org/10.3958/059.041.0330

Rana, K. L., Kour, D., Sheikh, I., Dhiman, A., Yadav, N., Yadav, A. N., Rastegari, A. A., Singh, K., Saxena, A. K. (2019). Endophytic Fungi: Biodiversity, Ecological Significance, and Potential Industrial Applications (pp. 1-62). Springer International Publishing. https://doi.org/10.1007/978-3-03010480-1_1

Razinger, J., Lutz, M., Schroers, H. J., Palmisano, M., Wohler, C., Urek, G., Grunder, J. (2014). Direct plantlet inoculation with soil or insect-associated fungi may control cabbage root fly maggots. Journal of Invertebrate Pathology, 120, 59-66. https://doi.org/10.1016/j.jip.2014.05.006

Reddy, G. V. P., Tangtrakulwanich, K., Wu, S., Miller, J. H., Ophus, V. L., Prewett, J., Jaronski, S. T. (2014). Evaluation of the effectiveness of entomopathogens for the management of wireworms (Coleoptera: Elateridae) on spring wheat. Journal of Invertebrate Pathology, 120, 43-49. https://doi. org/10.1016/j.jip.2014.05.005

Reddy, G. V. P., Zhao, Z., Humber, R. A. (2014). Laboratory and field efficacy of entomopathogenic fungi for the management of the sweetpotato weevil, Cylas formicarius (Coleoptera: Brentidae). Journal of Invertebrate Pathology, 122, 10-15. https://doi.org/10.1016/j.jip.2014.07.009

Renwick., A., Campbell, R., Coe, S. (1991). Assessment of in vivo screening systems for potential biocontrol agents of Gaeumannomyces graminis. Plant Pathology, 40(4), 524532. https://doi.org/10.1111/j.1365-3059.1991.tb02415.x

Rho, H., Hsieh, M., Kandel, S. L., Cantillo, J., Doty, S. L., Kim, S.-H. (2018). Do endophytes promote growth of host plants under stress? A meta-analysis on plant stress mitigation by endophytes. Microbial Ecology, 75(2), 407-418. https://doi. org/10.1007/s00248-017-1054-3

Robert-Seilaniantz, A., Grant, M., Jones, J. D. G. (2011). Hormone crosstalk in plant disease and defense: more than just jasmonate-salicylate antagonism. Annual Review of Phytopathology, 49, 317-343. https://doi.org/10.1146/annurev-phyto-073009-114447

Rodriguez, R. J., White, J. F., Arnold, A. E., Redman, R. S. (2009). Fungal endophytes: Diversity and functional roles: Tansley review. In New Phytologist (Vol. 182, Issue 2, pp. 314-330). John Wiley Sons, Ltd. https://doi.org/10.1111/ j.1469-8137.2009.02773.x

Rodriguez, R., Redman, R. (2008). More than 400 million years of evolution and some plants still can't make it on their own: plant stress tolerance via fungal symbiosis. Journal of Experimental Botany, 59(5), 1109-1114. https://doi. org/10.1093/jxb/erm342

Rondot, Y., Reineke, A. (2018). Endophytic Beauveria bassiana in grapevine Vitis vinifera (L.) reduces infestation with piercing-sucking insects. Biological Control, 116, 82-89. https://doi.org/10.1016/j.biocontrol.2016.10.006

Saikkonen, K., Wäli, P., Helander, M., Faeth, S. H. (2004). Evolution of endophyteplant symbioses. Trends in Plant Science, 9(6), 275-280. https://doi.org/10.1016/j.tplants.2004.04.005

Sandhu, S. S., Sharma, A. K., Beniwal, V., Goel, G., Batra, P., Kumar, A., Jaglan, S., Sharma, A. K., Malhotra, S. (2012). Myco-biocontrol of insect pests: Factors involved, mechanism, and regulation. Journal of Pathogens, 2012, 1-10. https://doi.org/10.1155/2012/126819

Sang Myeong, L., Woon Hong, Y., Hyeong Jin, J., Sang Chul, S., Yil Seong, M. (1999). Effect of entomopathogenic fungi on growth of cucumber and Rhizoctonia solani. FRI Journal of Forest Science Seoul, 62, 118-125. https://eurekamag.com/ research/003/417/003417068.php

Sasan, R. K., Bidochka, M. J. (2013). Antagonism of the endophytic insect pathogenic fungus Metarhizium robertsii against the bean plant pathogen Fusarium solani f. sp. phaseoli. Canadian Journal of Plant Pathology, 35(3), 288-293. https://doi.org/10.1080/07060661.2013.823114

Tefera, T., Vidal, S. (2009). Effect of inoculation method and plant growth medium on endophytic colonization of sorghum by the entomopathogenic fungus Beauveria bassiana. BioControl, 54(5), 663-669. https://doi.org/10.1007/ s10526-009-9216-y

Van Wees, S. C., Van der Ent, S., Pieterse, C. M. (2008). Plant immune responses triggered by beneficial microbes. In Current Opinion in Plant Biology (Vol. 11, Issue 4, pp. 443448). Elsevier Current Trends. https://doi.org/10.1016/j. pbi.2008.05.005

Vega, F. E. (2008). Insect pathology and fungal endophytes. Journal of Invertebrate Pathology, 98(3), 277-279. https:// doi.org/10.1016/j.jip.2008.01.008

Vega, F. E. (2018). The use of fungal entomopathogens as endophytes in biological control: a review. In Mycologia (Vol. 110, Issue 1, pp. 4-30). NLM (Medline). https://doi.org/10. 1080/00275514.2017.1418578

Vega, F. E., Goettel, M. S., Blackwell, M., Chandler, D., Jackson, M. A., Keller, S., Koike, M., Maniania, N. K., Monzón, A., Ownley, B. H., Pell, J. K., Rangel, D. E. N., Roy, H. E. (2009). Fungal entomopathogens: new insights on their ecology. In Fungal Ecology (Vol. 2, Issue 4, pp. 149-159). Elsevier. https://doi.org/10.1016/j.funeco.2009.05.001

Vidal, S., Jaber, L. R. (2015). Entomopathogenic fungi as endophytes: plantendophyteherbivore interactions and prospects for use in biological control. Current Science, 109(1), 46-54. http://www.jstor.org/stable/24905690

Wilson, D. (1995). Endophyte: The evolution of a term, and clarification of its use and definition. Oikos, 73(2), 274-276. https://doi.org/10.2307/3545919

Zamioudis, C., Pieterse, C. M. J. (2012). Modulation of host immunity by beneficial microbes. Molecular Plant-Microbe Interactions : MPMI, 25(2), 139-150. https://doi.org/10.1094/ MPMI-06-11-0179 